\title{
入出カデータ量を固定した逐次部分空間同定 アルゴリズム*
}

\author{
亀山建太郎 ${ }^{\dagger}$ 松浦 雄司 ${ }^{\dagger \dagger} \cdot$ 大住 晃 ${ }^{\dagger}$
}

\section{Recursive Subspace-based Identification Algorithm Using Fixed Input-Output Data*}

\author{
Kentaro KameYama ${ }^{\dagger}$, Yûji MatsuÜrA ${ }^{\dagger \ddagger}$ and Akira Ohsumi ${ }^{\dagger}$
}

\begin{abstract}
A recursive algorithm is derived for subspace system identification which is flexible and applicable to continuous/discrete-time, time-invariant/varying stochastic systems. Efficacy of the algorithm is demonstrated by simulations, comparing with another proposed algorithm.
\end{abstract}

\section{1. 緒 言}

近年，部分空間システム同定法は多入力多出力システ ムの線形状態空間表現を構築する有力なシステム同定法 として注目され，活発な研究が行われている [14], [17]. この同定法は長時間の入力データの集積をまってデータ 処理を行う，いわゆるバッチ処理が基本である。したがっ て，この方式では当然時間が経つにつれてデー夕量が増 え, これを計算機で処理することは計算機の容量の点か らも大きな負荷となる. しかも, この方式では時変シス テムに対処することは困難である.もちろん，時変シス テムに対しても，基本的にはバッチ処理を時々刻々繰り 返し適用すれば，次元の推定をも含めたシステム同定が 可能である [7]が，これによれば計算機とそれに付随し た記憶容量の増大化の問題が発生する. そこで, 計算量 と記憶容量双方の低減化を図るために逐次同定アルゴリ ズムの開発が望まれている。

部分空間同定法の基本は，マトリクスに関する二つの 分解演算, すなわち $L Q$ (あるいは $Q R$ ) 分解と（シス テムの次元を決定するための) 特異值分解より成り立っ

* 原稿受付 2003 年 12 月 3 日

$\dagger$ 京都工芸繊維大学 大学院 工芸科学研究科 Department of Mechanical \& System Engineering, Graduate School of Engineering and Science, Kyoto Instutute of Technology, Matsugasaki, Sakyo, Kyoto 606-8585, JAPAN

現：(株) 神戸製鋼所 技術開発本部 機械研究所 Dynamics \& Acoustics Research Section, Mechanical Engineering Research Laboratory, Kobe Steel, Ltd., 1-5-5 Takatsukadai, Nishi-ku, Kobe 651-2271, JAPAN

Key Words: subspace identification, recursive algorithm, stochastic system, time-varying system.
ている.したがって，上述の逐次同定アルゴリズムを開 発しようとすれば， $L Q$ 分解あるいは特異值分解のいず れかを逐次化するか，あるいはそれら両方を逐次化する 方法が考えられる。

たとえば, Verhaegen-Deprettere [15] は，時不変シ ステムに対して上述の両方の分解法を提案している. Gustafsson [2] は，システムの次元が既知であるという 仮定のもとで，拡大可観測マトリクスによって張られる 部分空間を track するEIV-PAST を適用するアルゴリ ズムを提案している. Oku-Kimura [10], [11] は圧縮され た出力データマトリクスに対する逐次アルゴリズム，お よび拡大可観測マトリクスの推定を行うのに勾配法を 用いた逐次アルゴリズムの二つの方法を提案している。 Lovera ら [4] は，アレー信号処理と部分空間同定法との 密接な関係に着目し，信号処理分野で数多く提案されて いる部分特異值分解のアイデアを適用することによって 逐次アルゴリズムを提案しているが，システムの次元に ついては触れていない. Takei ら [13] は拡大可観測マト リクスの推定に代わり, それにより低次元のシューア補部 分マトリクスに対して特異值分解を毎ステップ実行する 逐次アルゴリズムを，また Mercèreら [5] は propagator 法により拡大可観測マトリクスを二つの部分マトリクス に分割することによって逐次アルゴリズムを導出してい る。さらに, Lovera [3] は Lovera ら [4] の論文の延長線 で projector tracking 法により逐次アルゴリズムの改良 を試みている。

前述のように, 逐次アルゴリズムはオンライン同定を 目指すものであるから, 本来時変システムに対しても適 用可能であることが望まれる。これまでのほとんどの部 
分空間逐次同定アルゴリズムはシステムが時不変である という仮定のもとで得られる入出力代数方程式 (1) （次 章) に基づいて導出されているが，システムが時間的に ゆっくりと变化するという仮定をすれば，この式は近似 的に成り立つとみてよい [7], [15]. そのような観点から， 多くの研究では一般論は時不変システムが対象であって も, 数值シミュレーションでは時変システムを扱ってい るものが多い [2], [13]. また, 時変システムに対する数 值例による検証は数少ない $[12]$.

以上の背景に鑑み, 本論文では, 時変システムを念頭 におき，入出力データマトリクスの次元（データサイズ） を一定值に固定して $L Q$ 分解を逐次化するという方針を とる. 近年の計算機の容量, 計算速度などには飛躍的な 進化が見られ，データマトリクスの大きさを一定に固定 することは，アルゴリズムの逐次化に対してそれ程大き なマイナス要因にはならないと思われる。

\section{2. 入出力代数方程式と問題の記述}

部分空間同定法によるシステム同定では，システムと 出力の方程式はいずれも線形の状態空間モデルで表現さ れると仮定し, システムの状態量の次元とモデルの各係 数マトリクスを取得された入出力データの集積より決定 する，その基礎となるのは，それらの間に成り立つつぎ のような入出力代数方程式である:

$$
Y_{i}=\Gamma_{i} X_{i}+H_{i} U_{i}+\Sigma_{i} W_{i}+V_{i}
$$

ここで, $Y_{i} \in R^{i \ell \times N}, U_{i} \in R^{i m \times N}$ はそれぞれ出力 $y \in R^{\ell}$ と入力 $u \in R^{m}$ よりなる $i \ell$ 次元および $i m$ 次元べクト ルを $N$ 列並べて構成される出力と入力データマトリク ス, $X_{i} \in R^{n \times N}$ はシステム状態量 $x \in R^{n}$ より,また $W_{i} \in R^{i n \times N}, V_{i} \in R^{i \ell \times N}$ は, $Y_{i}, U_{i}$ と同様に, システ 厶雑音 $w \in R^{n}$ あるいは観測雑音 $v \in R^{\ell} よ り$ 構成される マトリクスである. また, $\Gamma_{i} \in R^{i \ell \times n}$ は拡大可観測マト リクス, $H_{i} \in R^{i \ell \times i m}, \Sigma_{i} \in R^{i \ell \times n}$ はいずれも下ブロッ ク三角マトリクスである（それらの具体的な構造および (1) 式の導出については参考文献（たとえば [14], [16]） を参照されたい).

入出力代数方程式 (1) は, システムが離散時間モデル で表現される場合はもちろんのこと, 連続時間モデルに 対しても著者らが提案している超関数の概念を用いた方 法により得られる $[6]$. すなわち, システムのモデルを平 均值零の正規性白色雑音 $w_{k}$ および $v_{k}$ をうける離散時間 時不変確率システム

$$
\Sigma_{D}:\left\{\begin{aligned}
x_{k+1} & =A x_{k}+B u_{k}+w_{k} \\
y_{k} & =C x_{k}+D u_{k}+v_{k}
\end{aligned}\right.
$$

として与える場合には, 出力データマトリクス $Y_{i} \in R^{i \ell \times N}$ は， $(N+i-2)$ ステップ過去から現在までに得られた データ $\left\{y_{j}\right\}_{j=k-N-i+2, \cdots, k-1, k}$ をもとに, $N$ 個の $i \ell$ 次
元ベクトル $y_{i}(j)=\left[y_{j-i+1}^{\mathrm{T}}, \cdots, y_{j-1}^{\mathrm{T}}, y_{j}^{\mathrm{T}}\right]^{\mathrm{T}}$ $(j=k-N+1, \cdots, k-1, k)$ を定義して並べることによっ てハンケルマトリクス

$$
Y_{i}=\left[y_{i}(k-N+1), \cdots, y_{i}(k-1), y_{i}(k)\right]
$$

として構成される。このとき，マトリクス $U_{i}, W_{i}, V_{i}$ は 同様な構造をもつマトリクスであり， $X_{i}$ は

$$
X_{i}=\left[x_{k-N-i+2}, \cdots, x_{k-i}, x_{k-i+1}\right]
$$

で与えられる。

また, 平均值零の正規性白色雑音 $w(t), v(t)$ をうける 連続時間時不変確率システム

$$
\Sigma_{C}:\left\{\begin{array}{l}
\dot{x}(t)=A x(t)+B u(t)+w(t) \\
y(t)=C x(t)+D u(t)+v(t)
\end{array}\right.
$$

を与える場合には，つぎのようにして超関数の概念を 用いた方法により入出力方程式 (1) を得る。すなわち, $N$ 個の離散時刻 $\left\{t_{k-N+1}, \cdots, t_{k-1}, t_{k}\right\}$ において, デー 夕 $y(\cdot)$ を時点 $t_{j}$ を指標としてもつ $C^{\infty}$ 級スカラ関数 $\varphi\left(\cdot ; t_{j}\right)$ を用いて加工し, $i \ell$ 次元べクトル $y_{i}(\varphi)\left(t_{j}\right)=$ $\left[y^{\mathrm{T}}(\varphi)\left(t_{j}\right), \cdots,(-1)^{i-1} y^{\mathrm{T}}\left(\varphi^{(i-1)}\right)\left(t_{j}\right)\right]^{\mathrm{T}}$ を作り, これ を順に $N$ 個並べることによって，データマトリクス $Y_{i}=Y_{i}(\varphi)$ を

$$
Y_{i}(\varphi)=\left[y_{i}(\varphi)\left(t_{k-N+1}\right), \cdots, y_{i}(\varphi)\left(t_{k-1}\right), y_{i}(\varphi)\left(t_{k}\right)\right]
$$

として構成する。ここで, $y\left(\varphi^{(k)}\right)\left(t_{j}\right)=\int_{-\infty}^{\infty} y(t) \varphi^{(k)}(t$; $\left.t_{j}\right) d t$ は時点 $t=t_{j}$ における $y(t)$ の形式的な (すなわち, 超関数の意味の) $k$ 階微分值 $y^{(k)}(t)$ である. $U_{i}=U_{i}(\varphi)$, $W_{i}=W_{i}(\varphi), V_{i}=V_{i}(\varphi)$ も同様な構造を有し, 状態量マ トリクス $X_{i}(\varphi)$ は

$$
X_{i}(\varphi)=\left[x(\varphi)\left(t_{k-N+1}\right), \cdots, x(\varphi)\left(t_{k-1}\right), x(\varphi)\left(t_{k}\right)\right]
$$

と与えられる。なお，マトリクス $\Gamma_{i}, H_{i}, \Sigma_{i}$ は離散時 間モデルの場合と全く同じ構造を持つ.

上述のように，システム $\Sigma_{D}, \Sigma_{C}$ いずれの場合にも入 出力関係は代数方程式 (1)で与えられる. したがって, 以 下では $\Sigma_{D}, \Sigma_{C}$ いずれとも区別することなく，(1) 式に 基づいてオンライン同定アルゴリズムを導出する。その ため，時間変数 $k$ あるいは $t_{k}$ を現在時刻とし，(1) 式を

$$
\begin{aligned}
& Y_{i}(k \mid k-N+1)=\Gamma_{i}(k) X_{i}(k \mid k-N+1) \\
& +H_{i}(k) U_{i}(k \mid k-N+1)+\Sigma_{i}(k) W_{i}(k \mid k-N+1) \\
& \quad+V_{i}(k \mid k-N+1)
\end{aligned}
$$

と表現しなおす。ここで，記号 $Y_{i}(k \mid k-N+1)$ の引数 $k$ は現在時刻を, また $k-N+1$ はデータマトリクスを構 成する $N$ 列べクトルの開始時刻を意味する。すなわち,

$Y_{i}(k \mid k-N+1)$ 


$$
\begin{aligned}
& =\left[y_{i}(k-N+1), \cdots, y_{i}(k-1), y_{i}(k)\right] \quad \text { for } \Sigma_{D} \\
& =\left[y_{i}(\varphi)\left(t_{k-N+1}\right), \cdots, y_{i}(\varphi)\left(t_{k-1}\right), y_{i}(\varphi)\left(t_{k}\right)\right]
\end{aligned}
$$

for $\Sigma_{C}$

である。また，マトリクス $\Gamma_{i}, H_{i}$ ，拈よび $\Sigma_{i}$ について も, 時変システムマトリクス $\left(A_{k}, B_{k}, C_{k}, D_{k}\right)$, あるい は $(A(t), B(t), C(t), D(t))$ にも対応できるように引数 $k$ を導入した。

さて, 以上の準備のもとで, 現在時刻までに得られ た入出力デー夕 $U_{i}(k \mid k-N+1), Y_{i}(k \mid k-N+1)$ に基 ついて, 時変/時不変システムの次元 $n$ とマトリクス $(A, B, C, D)$ を同定する逐次アルゴリズムを導出するの が本論文の目的である。ただし，データマトリクスの大 きさを決める整数 $i$ はシステムの次元 $n$ より十分大きく とるという条件は暗黙のうちに仮定する.

\section{3. 逐次アルゴリズム}

本章では, 入出力データマトリクスの大きさを決定す る次元 $N$ を固定した逐次アルゴリズムを導出する.

まず，雑音項の影響を除去する目的で $U_{i}(k \mid k-N+1)$ と同様な構造を持つ補助变数マトリクス $U_{h}(k \mid k-N+$ 1) $\in R^{h m \times N}$ を $U_{i}(k \mid k-N+1)$ と独立に構成する.これ は，たとえば

$$
\begin{aligned}
& U_{h}(k \mid k-N+1) \\
& \quad=\left[u_{h}(k-i-N+1), \cdots, u_{h}(k-i)\right] \text { for } \Sigma_{D} \\
& \quad=\left[u_{h}(\psi)\left(t_{k-N+1}\right), \cdots, u_{h}(\psi)\left(t_{k}\right)\right] \text { for } \Sigma_{C}
\end{aligned}
$$

のようにとる.ここで, システム $\Sigma_{D}$ に対しては $u_{h}(j)=$ $\left[u_{j-h+1}^{\mathrm{T}}, \cdots, u_{j-1}^{\mathrm{T}}, u_{j}^{\mathrm{T}}\right]^{\mathrm{T}}$, また $\Sigma_{C}$ については関数 $\varphi\left(\cdot ; t_{j}\right)$ とは異なる別の $C^{\infty}$ 級スカラ関数 $\psi\left(\cdot ; t_{j}\right)$ を用いること によって生成する。 そこでつぎのような $(2 i+h) \times N$ 次 元マトリクスの $L Q$ 分解を行う:

$$
\begin{aligned}
& {\left[\begin{array}{c}
U_{i}(k \mid k-N+1) \\
U_{h}(k \mid k-N+1) \\
Y_{i}(k \mid k-N+1)
\end{array}\right]} \\
& \quad=\left[\begin{array}{ccc}
L_{11}(k) & 0 & 0 \\
L_{21}(k) & L_{22}(k) & 0 \\
L_{31}(k) & L_{32}(k) & L_{33}(k)
\end{array}\right]\left[\begin{array}{c}
Q_{1}^{\mathrm{T}}(k) \\
Q_{2}^{\mathrm{T}}(k) \\
Q_{3}^{\mathrm{T}}(k)
\end{array}\right]
\end{aligned}
$$

この分解により, 拡大可観測マトリクス $\Gamma_{i}(k)$ の張る部 分空間が $L$-マトリクスの要素によって決定できることが 知られている。すなわち，

$$
\frac{1}{\sqrt{N}} L_{32}(k)=\Gamma_{i}(k) \frac{1}{\sqrt{N}} X_{i}(k \mid k-N+1) Q_{2}(k)
$$

の関係が得られる。したがって，(6)式の左辺 $(1 / \sqrt{N})$ $\cdot L_{32}(k)$ の特異值分解（あるいは $(1 / N) L_{32}(k) L_{32}^{\mathrm{T}}(k)$ の 固有值分解) によって, システムの次元 $n$ と拡大可観測
マトリクス $\Gamma_{i}(k)$ を同定する.この結果を用いて, (正則 なマトリクス $T$ にり変換された）システムマトリクス の組 $\left(A_{T}, C_{T}\right)$ を決定することができる(ここで添字 $T$ は マトリクス $T$ による相似変換, すなわち $A_{T}=T A T^{-1}$, $\left.C_{T}=C T^{-1}\right)$. さらに, $\Gamma_{i}(k)$ の同定值を $U_{n}(k)$ とする と, その直交補空間 $U_{n}^{\perp}(k)$ に対して，(5) 式より次式を 得る:

$$
\left\{U_{n}^{\perp}(k)\right\}^{\mathrm{T}} L_{31}(k) L_{11}^{-1}(k)=\left\{U_{n}^{\perp}(k)\right\}^{\mathrm{T}} H_{i}(k)
$$

これより残りのシステムマトリクスの組 $\left(B_{T}, D\right)\left(B_{T}=\right.$ $T B)$ を決定することができる $[16]$. このように，システ ムの次元 $n$ とマトリクス $\left(A_{T}, B_{T}, C_{T}, D\right)$ を決定するた めには, 結局 $L Q$ 分解の $L$ 要素がわかればシステムの同 定が可能であり，その逐次更新が実行できれば逐次アル ゴリズムが得られることになる。

以上の議論を踏まえて，つぎに逐次アルゴリズムの導 出を行う. いま, $k+1$ 時点で得られた新しい入力と出力, $\left\{u_{k+1}, y_{k+1}\right\}$, あるいは $\left\{u\left(t_{k+1}\right), y\left(t_{k+1}\right)\right\}$ をもとに， 入出力ベクトル $u_{i}(k+1), u_{h}(k+1)$ および $y_{i}(k+1)$ を 構成し，これを $k$ 時点までの入出力データマトリクスに 含めると,つぎの関係式を得る:

$$
\begin{aligned}
& {\left[\begin{array}{c}
U_{i}(k \mid k-N+1) \vdots u_{i}(k+1) \\
U_{h}(k \mid k-N+1) \vdots u_{h}(k+1) \\
Y_{i}(k \mid k-N+1) \vdots y_{i}(k+1)
\end{array}\right]} \\
& \quad=\left[\begin{array}{c}
u_{i}(k-N+1) \vdots U_{i}(k+1 \mid k-N+2) \\
u_{h}(k-N+1) \vdots U_{h}(k+1 \mid k-N+2) \\
y_{i}(k-N+1) \vdots Y_{i}(k+1 \mid k-N+2)
\end{array}\right]
\end{aligned}
$$

この関係式は, Choら [1], Loveraら [4]によって提案さ れている update/downdate 方式，すなわち新しいデー タによってデータマトリクスを更新してデータサイズを 一定に保つために古いデータをそれから除く仕方を簡潔 に表したものであり，以下，本論文で逐次同定アルゴリ ズムを導くにあたっての鍵となる。

さて，ステップ $k+1$ に扔ける $(i m+h m+i \ell) \times N$ 次 元データマトリクスの $L Q$ 分解は

$\left[\begin{array}{c}U_{i}(k+1 \mid k-N+2) \\ U_{h}(k+1 \mid k-N+2) \\ Y_{i}(k+1 \mid k-N+2)\end{array}\right]=$

$\left[\begin{array}{ccc}L_{11}(k+1) & 0 & 0 \\ L_{21}(k+1) & L_{22}(k+1) & 0 \\ L_{31}(k+1) & L_{32}(k+1) & L_{33}(k+1)\end{array}\right]\left[\begin{array}{c}Q_{1}^{\mathrm{T}}(k+1) \\ Q_{2}^{\mathrm{T}}(k+1) \\ Q_{3}^{\mathrm{T}}(k+1)\end{array}\right](9)$

と与えられる。.以下式の展開にあたって，(5) および $(9)$ 式の右辺をそれぞれ 


$$
\left[\begin{array}{c}
L_{11}(\cdot) Q_{1}^{\mathrm{T}}(\cdot) \\
L_{21}(\cdot) Q_{1}^{\mathrm{T}}(\cdot)+L_{22}(\cdot) Q_{2}^{\mathrm{T}}(\cdot) \\
L_{31}(\cdot) Q_{1}^{\mathrm{T}}(\cdot)+L_{32}(\cdot) Q_{2}^{\mathrm{T}}(\cdot)+L_{33}(\cdot) Q_{3}^{\mathrm{T}}(\cdot)
\end{array}\right]
$$

と表現する。この (5) および (9) 式の $L Q$ 分解表現をそ れぞれ(8) 式の左辺および右辺に代入すると次式が得ら れる。

$$
\begin{aligned}
& {\left[L_{11}(k) Q_{1}^{\mathrm{T}}(k)\right.} \\
& L_{21}(k) Q_{1}^{\mathrm{T}}(k)+L_{22}(k) Q_{2}^{\mathrm{T}}(k) \\
& L_{31}(k) Q_{1}^{\mathrm{T}}(k)+L_{32}(k) Q_{2}^{\mathrm{T}}(k)+L_{33}(k) Q_{3}^{\mathrm{T}}(k) \vdots \\
& \left.\begin{array}{c}
u_{i}(k+1) \\
u_{h}(k+1) \\
y_{i}(k+1)
\end{array}\right]=\left[\begin{array}{c}
u_{i}(k-N+1) \vdots \\
u_{h}(k-N+1) \vdots \\
y_{i}(k-N+1) \vdots
\end{array}\right. \\
& L_{11}(k+1) Q_{1}^{\mathrm{T}}(k+1) \\
& L_{21}(k+1) Q_{1}^{\mathrm{T}}(k+1)+L_{22}(k+1) Q_{2}^{\mathrm{T}}(k+1) \\
& L_{31}(k+1) Q_{1}^{\mathrm{T}}(k+1)+L_{32}(k+1) Q_{2}^{\mathrm{T}}(k+1) \\
& \left.+L_{33}(k+1) Q_{3}^{\mathrm{T}}(k+1)\right]_{(10)}
\end{aligned}
$$

つぎに，(10)式の左辺にそれ自身の転置を，また右 辺にはそれ自身の転置をかける。すなわち，(10)式を $[A \vdots b]=[c \vdots D]$ の形のマトリクスと見ると，

$$
[A \vdots b][A \vdots b]^{\mathrm{T}}=[c \vdots D][c \vdots D]^{\mathrm{T}}
$$

より

$$
A A^{\mathrm{T}}+b b^{\mathrm{T}}=c c^{\mathrm{T}}+D D^{\mathrm{T}}
$$

の等式を得る.まず左辺に対する演算 $[A \vdots b][A \vdots b]^{\mathrm{T}}=$ $A A^{\mathrm{T}}+b b^{\mathrm{T}}$ は, $Q_{i}^{\mathrm{T}}(\cdot) Q_{j}(\cdot)=I \delta_{i j}(i, j=1,2,3) \quad\left(\delta_{i j}:\right.$ クロネッカーデルタ）に留意するとつぎのようになる。

$$
\begin{aligned}
& {\left[\begin{array}{c}
L_{11}(k) Q_{1}^{\mathrm{T}}(k) \\
L_{21}(k) Q_{1}^{\mathrm{T}}(k)+L_{22}(k) Q_{2}^{\mathrm{T}}(k) \\
L_{31}(k) Q_{1}^{\mathrm{T}}(k)+L_{32}(k) Q_{2}^{\mathrm{T}}(k)+L_{33}(k) Q_{3}^{\mathrm{T}}(k) \\
\vdots u_{i}(k+1) \\
\vdots u_{h}(k+1) \\
\vdots y_{i}(k+1)
\end{array}\right]\left[\begin{array}{c} 
\\
(\text { same })
\end{array}\right]} \\
& =\left[\begin{array}{cc}
L_{11}(k) L_{11}^{\mathrm{T}}(k) & L_{11}(k) L_{21}^{\mathrm{T}}(k) \\
L_{21}(k) L_{11}^{\mathrm{T}}(k) & L_{21}(k) L_{21}^{\mathrm{T}}(k)+L_{22}(k) L_{22}^{\mathrm{T}}(k) \\
L_{31}(k) L_{11}^{\mathrm{T}}(k) & L_{31}(k) L_{21}^{\mathrm{T}}(k)+L_{32}(k) L_{22}^{\mathrm{T}}(k)
\end{array}\right. \\
& L_{11} L_{31}^{\mathrm{T}}(k) \\
& L_{21}(k) L_{31}^{\mathrm{T}}(k)+L_{22}(k) L_{32}^{\mathrm{T}}(k) \\
& \left.L_{31}(k) L_{31}^{\mathrm{T}}(k)+L_{32}(k) L_{32}^{\mathrm{T}}(k)+L_{33}(k) L_{33}^{\mathrm{T}}(k)\right]
\end{aligned}
$$

$$
\begin{aligned}
& +\left[\begin{array}{cc}
u_{i}(k+1) u_{i}^{\mathrm{T}}(k+1) & u_{i}(k+1) u_{h}^{\mathrm{T}}(k+1) \\
u_{h}(k+1) u_{i}^{\mathrm{T}}(k+1) & u_{h}(k+1) u_{h}^{\mathrm{T}}(k+1) \\
y_{i}(k+1) u_{i}^{\mathrm{T}}(k+1) & y_{i}(k+1) u_{h}^{\mathrm{T}}(k+1)
\end{array}\right. \\
& u_{i}(k+1) y_{i}^{\mathrm{T}}(k+1) \\
& u_{h}(k+1) y_{i}^{\mathrm{T}}(k+1) \\
& \left.y_{i}(k+1) y_{i}^{\mathrm{T}}(k+1)\right]
\end{aligned}
$$

同様に, 右辺に対する演算 $[c \vdots D][c \vdots D]^{\mathrm{T}}=c c^{\mathrm{T}}+$ $D D^{\mathrm{T}}$ についても行うと, その結果は次のようになる.

$$
\left[\begin{array}{r}
u_{i}(k-N+1) u_{i}^{\mathrm{T}}(k-N+1) \\
u_{h}(k-N+1) u_{i}^{\mathrm{T}}(k-N+1) \\
y_{i}(k-N+1) u_{i}^{\mathrm{T}}(k-N+1) \\
u_{i}(k-N+1) u_{h}^{\mathrm{T}}(k-N+1) \\
u_{h}(k-N+1) u_{h}^{\mathrm{T}}(k-N+1) \\
y_{i}(k-N+1) u_{h}^{\mathrm{T}}(k-N+1) \\
u_{i}(k-N+1) y_{i}^{\mathrm{T}}(k-N+1) \\
u_{h}(k-N+1) y_{i}^{\mathrm{T}}(k-N+1) \\
y_{i}(k-N+1) y_{i}^{\mathrm{T}}(k-N+1)
\end{array}\right]
$$$$
+\left[\begin{array}{cc}
L_{11}(k+1) L_{11}^{\mathrm{T}}(k+1) & L_{11}(k+1) L_{21}^{\mathrm{T}}(k+1) \\
L_{21}(k+1) L_{11}^{\mathrm{T}}(k+1) & L_{21}(k+1) L_{21}^{\mathrm{T}}(k+1) \\
& +L_{22}(k+1) L_{22}^{\mathrm{T}}(k+1) \\
L_{31}(k+1) L_{11}^{\mathrm{T}}(k+1) & L_{31}(k+1) L_{21}^{\mathrm{T}}(k+1) \\
+L_{32}(k+1) L_{22}^{\mathrm{T}}(k+1) \\
L_{11}(k+1) L_{31}^{\mathrm{T}}(k+1) \\
L_{21}(k+1) L_{31}^{\mathrm{T}}(k+1)+L_{22}(k+1) L_{32}^{\mathrm{T}}(k+1) \\
L_{31}(k+1) L_{31}^{\mathrm{T}}(k+1)+L_{32}(k+1) L_{32}^{\mathrm{T}}(k+1) \\
+L_{33}(k+1) L_{33}^{\mathrm{T}}(k+1)
\end{array}\right]
$$

ここで記号の簡単化のために，(11) 式右辺第 1 項および (12) 式第 2 項の $3 \times 3$ 次元マトリクスの各要素に対して $\left\{\hat{L}_{i}(k), i=0,1, \cdots, 5\right\}$ を

$$
\begin{aligned}
\hat{L}_{0}(k)= & L_{11}(k) L_{11}^{\mathrm{T}}(k) \\
\hat{L}_{1}(k)= & L_{21}(k) L_{11}^{\mathrm{T}}(k) \\
\hat{L}_{2}(k)= & L_{31}(k) L_{11}^{\mathrm{T}}(k) \\
\hat{L}_{3}(k)= & L_{21}(k) L_{21}^{\mathrm{T}}(k)+L_{22}(k) L_{22}^{\mathrm{T}}(k) \\
\hat{L}_{4}(k)= & L_{31}(k) L_{21}^{\mathrm{T}}(k)+L_{32}(k) L_{22}^{\mathrm{T}}(k) \\
\hat{L}_{5}(k)= & L_{31}(k) L_{31}^{\mathrm{T}}(k)+L_{32}(k) L_{32}^{\mathrm{T}}(k) \\
& +L_{33}(k) L_{33}^{\mathrm{T}}(k)
\end{aligned}
$$

と定義すると，(11)式と (12) 式を等置することによって $\left\{\hat{L}_{i}(k)\right\}$ に対する逐次関係式を得る:

$$
\begin{aligned}
\hat{L}_{0}(k+1)= & \hat{L}_{0}(k)+u_{i}(k+1) u_{i}^{\mathrm{T}}(k+1) \\
& -u_{i}(k-N+1) u_{i}^{\mathrm{T}}(k-N+1)
\end{aligned}
$$




$$
\begin{gathered}
\hat{L}_{1}(k+1)=\hat{L}_{1}(k)+u_{h}(k+1) u_{i}^{\mathrm{T}}(k+1) \\
-u_{h}(k-N+1) u_{i}^{\mathrm{T}}(k-N+1) \\
\hat{L}_{2}(k+1)=\hat{L}_{2}(k)+y_{i}(k+1) u_{i}^{\mathrm{T}}(k+1) \\
-y_{i}(k-N+1) u_{i}^{\mathrm{T}}(k-N+1) \\
\hat{L}_{3}(k+1)=\hat{L}_{3}(k)+u_{h}(k+1) u_{h}^{\mathrm{T}}(k+1) \\
-u_{h}(k-N+1) u_{h}^{\mathrm{T}}(k-N+1) \\
\hat{L}_{4}(k+1)=\hat{L}_{4}(k)+y_{i}(k+1) u_{h}^{\mathrm{T}}(k+1) \\
-y_{i}(k-N+1) u_{h}^{\mathrm{T}}(k-N+1) \\
\hat{L}_{5}(k+1)=\hat{L}_{5}(k)+y_{i}(k+1) y_{i}^{\mathrm{T}}(k+1) \\
-y_{i}(k-N+1) y_{i}^{\mathrm{T}}(k-N+1)
\end{gathered}
$$

さて，前述のようにシステムマトリクスと次元を同定 するにあたっては, $L_{32}(k) L_{32}^{\mathrm{T}}(k)$ と $L_{31}(k) L_{11}^{-1}(k)$ が必 要である。まず, (17) 式より次式が得られる:

$$
L_{32}(k)=\left\{\hat{L}_{4}(k)-L_{31}(k) L_{21}^{\mathrm{T}}(k)\right\}\left\{L_{22}^{\mathrm{T}}(k)\right\}^{-1}(25
$$

(15) 式より $L_{31}(k)$ を，また $(14)$ 式より $L_{21}(k)$ を求め ると，

$$
L_{31}(k) L_{21}^{\mathrm{T}}(k)=\hat{L}_{2}(k) \hat{L}_{0}^{-1}(k) \hat{L}_{1}^{\mathrm{T}}(k)
$$

を得る。同様にして (16) 式より (13)，(14) 式を考慮して

$$
L_{22}(k) L_{22}^{\mathrm{T}}(k)=\hat{L}_{3}(k)-\hat{L}_{1}(k) \hat{L}_{0}^{-1}(k) \hat{L}_{1}^{\mathrm{T}}(k)
$$

を得る。したがって，(25) 式より積 $L_{32}(k) L_{32}^{\mathrm{T}}(k)$ を求 め，(26)，(27) 式を用いると次式を得る:

$$
\begin{aligned}
L_{32}(k) L_{32}^{\mathrm{T}}(k)= & \left\{\hat{L}_{4}(k)-\hat{L}_{2}(k) \hat{L}_{0}^{-1}(k) \hat{L}_{1}^{\mathrm{T}}(k)\right\} \\
& \cdot\left\{\hat{L}_{3}(k)-\hat{L}_{1}(k) \hat{L}_{0}^{-1}(k) \hat{L}_{1}^{\mathrm{T}}(k)\right\}^{-1} \\
& \cdot\left\{\hat{L}_{4}(k)-\hat{L}_{2}(k) \hat{L}_{0}^{-1}(k) \hat{L}_{1}^{\mathrm{T}}(k)\right\}^{\mathrm{T}}
\end{aligned}
$$

また, $L_{31}(k) L_{11}^{-1}(k)$ は, $(15)$ 式と $\hat{L}_{0}(k)$ の定義より直 ちに次のように得られる:

$$
L_{31}(k) L_{11}^{-1}(k)=\hat{L}_{2}(k) \hat{L}_{0}^{-1}(k)
$$

以上の結果より，逐次同定アルゴリズムは次のように 与えられる。な押, 同定にあたって $\hat{L}_{5}(\cdot)$ は必要とされ ない.

[逐次部分空間同定アルゴリズム]

Step 0: [初期設定] まずデータマトリクスの大きさを決め る次元 $i$ 抢よび $h$ を設定する. 同定開始にあたっ て，十分に入出力デー夕を取得し，それに対応 して $N$ を固定する. 初期情報として $(k=0$ に対 する）入出力データマトリクス $U_{i}(0 \mid-N+1)$, $U_{h}(0 \mid-N+1)$ および $Y_{i}(0 \mid-N+1)$ を構成し て (5) 式により $L Q$ 分解を行い, $L$-要素よりな るマトリクス $\left\{\hat{L}_{i}(0), i=0,1, \cdots, 4\right\}$ を求める.

Step 1: 第 $(k+1)$ ステップで新しく入手される入出力
デー夕 $\{u(k+1), y(k+1)\}$ より，第 $(k+1)$ ス テップでの入出力ベクトル $u_{i}(k+1), y_{i}(k+1)$ および $u_{h}(k+1)$ を構成し, 前段階（第 $k$ 久 テップ）で得られている $\left\{\hat{L}_{i}(k), i=0,1, \cdots, 4\right\}$ を $(19) \sim(23)$ 式により更新する.

Step 2: つぎに, $(28)$ 式より $L_{32}(k+1) L_{32}^{\mathrm{T}}(k+1)$ を計 算する。

Step 3: Step 2 で得られたマトリクスの固有值分解を 行う:

$$
\begin{gathered}
L_{32}(k+1) L_{32}^{\mathrm{T}}(k+1)=\left[U_{n}(k+1) U_{n}^{\perp}(k+1)\right. \\
\cdot\left[\begin{array}{cc}
S_{1}^{2}(k+1) & 0 \\
0 & S_{2}^{2}(k+1)
\end{array}\right]\left[\begin{array}{c}
U_{n}^{\mathrm{T}}(k+1) \\
\left\{U_{n}^{\perp}(k+1)\right\}^{\mathrm{T}}
\end{array}\right]
\end{gathered}
$$

これよりシステムの次元 $n$ が決定できる.

Step 4: Step 3 で得られた $U_{n}^{\perp}(k+1) \in R^{i \ell \times n}$ より, シ ステムマトリクスの組 $\left(A_{T}, C_{T}\right)$ を求める.

Step 5: ついで, (29) 式より $L_{31}(k+1) L_{11}^{-1}(k+1)$ を計 算し, これとStep 3 で得た $U_{n}^{\perp}(k+1)$ とから, (7) 式の関係より残りのシステムマトリクスの 組 $\left(B_{T}, D\right)$ を求める.

以上, $k=0,1,2, \cdots$ として Step 1 Step 5 を繰り返 すことによってシステムの次元とシステムマトリクス $\left(A_{T}, B_{T}, C_{T}, D\right)$ の同定值を逐次更新する。な扮, Steps 4,5 に执いてシステムマトリクスを決定する方法につい ては文献 [16]を参照されたい。

本アルゴリズムは, 入出力データマトリクスの $L Q$ 分 解の $L$-要素を直接更新する方法であり, 次のような特徵 がある. (i) $L Q$ 分解は $k=0$ (Step 0) においてただ 1 回 だけであり, (ii) それ以後は $L$-要素の繰返しのみでよい. (iii) 毎時間ステップで固有值分解を実行しなければなら

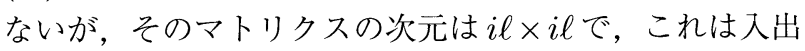
カデータマトリクスの次元に比べればはるかに低次元で ある. 本論文の基本的な考え方はデータサイズを一定に 保つ update/downdate にあり，前述したようにこの考 え方は Cho ら [1] や Loevra ら [4]によって提案されてい る. Choら [1]のアルゴリズムでは, 出力データの射影マ トリクスと観測雑音の共分散マトリクスのそれぞれの更 新が必要であり，かつ後者の更新ではそれを generator ベクトルに分解した上で並べ替えの作業をするなど，入 出力デー夕による更新にいたるまでの過程は煩雑であ る。さらには，彼らの開発した高速部分空間分解により 信号部分空間の導出を行うなど，全体として非常に複 雑なアルゴリズムとなっている。また，Loevra ら [4]は MOESP(multivariable output-error state space) クラ スの部分空間同定アルゴリズムを導出しているが，や や複雑である。これらのアルゴリズムに比べれは, 本 論文で提案した逐次アルゴリズムは, 入出力データの update/downdateの基礎式である（8)式に基づくだけで 
導出でき，直感的でしかも直截的である。

本論文で提案したアルゴリズムでは，データマトリク スの大きさを決める次元 $N$ は一定值に固定されている が，これを固定しない逐次同定アルゴリズムも同様な考 え方で導出することができる $[8]$.

\section{4. 他のアルゴリズムとの比較}

\section{1 アプローチによる比較}

緒言で述べたように，3. で提案した逐次アルゴリズム 以外にもいくつかの逐次部分空間同定アルゴリズムが提 案されている。まず，他の逐次アルゴリズムとアプロー チという観点から比較を行う。ただし, 記号の簡単化の ために，データマトリクスを $Y_{i}, U_{i}$ と記述する。

A. Okuの逐次アルゴリズムとの比較

$\mathrm{Oku}[9]$ のアルゴリズムでは, 出力データマトリクスの 重みつき射影により $L_{32}(k)$ 要素を取り出し, マトリクス

$$
L_{32}(k) L_{32}^{\mathrm{T}}(k)=Y_{i} \Pi_{U_{i}}^{\perp} \Phi^{\mathrm{T}} \Psi \Phi \Pi_{U_{i}}^{\perp} Y_{i}^{\mathrm{T}}
$$

を求め, これの逐次更新を行う。ここで, $\Pi_{U_{i}}^{\perp}$ は $\Pi_{U_{i}}:=$ $U_{i}^{\mathrm{T}}\left(U_{i} U_{i}^{\mathrm{T}}\right) U_{i}$ と定義するとき $\Pi_{U_{i}}^{\perp}=I-\Pi_{U_{i}}$ であるマ トリクスであり， $\Phi$ は本論文の $U_{h}(\cdot)$ に相当する補助変 数マトリクス, また $\Psi=\left(\Phi^{\mathrm{T}} \Pi_{U_{i}} \frac{1}{} \Phi\right)^{-1}$ である. Okuの方 法では， $Y_{i} \Pi_{U_{i}}^{\perp} \Phi$ と $\Psi$ の逐次更新を行うが, これらに(5) 式の $L Q$ 分解を施すと次の結果が得られ, 結局 (28) 式の 計算は 3. で導出したものと同じであることがわかる:

$$
\begin{aligned}
Y_{i} \Pi_{U_{i}}^{\perp} \Phi^{\mathrm{T}} & =Y_{i}\left[I-U_{i}^{\mathrm{T}}\left(U_{i} U_{i}^{\mathrm{T}}\right)^{-1} U_{i}\right] \Phi^{\mathrm{T}} \\
& =Y_{i} \Phi^{\mathrm{T}}-Y_{i} U_{i}^{\mathrm{T}}\left(U_{i} U_{i}^{\mathrm{T}}\right)^{-1} U_{i} \Phi^{\mathrm{T}} \\
& =\hat{L}_{4}-\hat{L}_{2} \hat{L}_{0}^{-1} \hat{L}_{1}^{\mathrm{T}} \\
\Phi \Pi_{U_{i}}^{\perp} \Phi^{\mathrm{T}} & =\Phi\left[I-U_{i}^{\mathrm{T}}\left(U_{i} U_{i}^{\mathrm{T}}\right)^{-1} U_{i}\right] \Phi^{\mathrm{T}} \\
& =\Phi \Phi^{\mathrm{T}}-\Phi U_{i}^{\mathrm{T}}\left(U_{i} U_{i}^{\mathrm{T}}\right)^{-1} U_{i} \Phi^{\mathrm{T}} \\
& =\hat{L}_{3}-\hat{L}_{1} \hat{L}_{0}^{-1} \hat{L}_{1}^{\mathrm{T}}
\end{aligned}
$$

B. Takei らの逐次アルゴリズムとの比較

Takeiら [13]のアルゴリズムでは，シューア補部分マ トリクスの考え方を用いることにより，マトリクス

$$
L_{32}(k) L_{32}^{\mathrm{T}}(k)=Y_{i} \Pi_{\Omega} \Pi_{U_{i}}^{\perp} \Pi_{\Omega} Y_{i}^{\mathrm{T}}
$$

の更新を行う.ここで， $\Omega=\left[U_{i}^{\mathrm{T}}, \Phi^{\mathrm{T}}\right]^{\mathrm{T}}$ である。また (34) 式は $\hat{E}=Y_{i}-\hat{G} U_{i}, \hat{E}^{*}=Y_{i}-\hat{G}^{*} U_{i}, \hat{E}=Y_{i} \Pi_{U_{i}}^{\perp}$, $\hat{E}^{*}=Y_{i} \Pi_{\Omega}^{\perp}$ とおくことにより,

$$
Y_{i} \Pi_{\Omega} \Pi_{U_{i}}^{\perp} \Pi_{\Omega} Y_{i}^{\mathrm{T}}=\hat{E} \hat{E}^{\mathrm{T}}-\hat{E} \hat{E}^{* \mathrm{~T}}
$$

と変形できる。これを残差平方和とみて $(35)$ 式の逐次更 新を行っている.ここでも, 直接 $L_{32}(k) L_{32}^{\mathrm{T}}(k)$ を求め ていることから, $\mathrm{Oku}$ の方法と同様にアルゴリズム中に 逆マトリクスの更新を含んでいることが推測される（ア ルゴリズムの詳細は [13] を参照されたい)。

これらよりわかるように, Oku と Takei らのアルゴ
リズムでは $\Psi=\left(\Phi^{\mathrm{T}} \Pi_{U_{i}}^{\perp} \Phi\right)^{-1}$ と逆マトリクスの更新に よって構成されているのに対し，3.のアルゴリズムでは $(19) \sim(23)$ 式に示したマトリクスの更新となっているこ とが相違点となっている。

\section{2 時変システムの同定への適用}

つぎに, 時変システムの同定問題への適用という視点か ら比較を行う. Verhaegen-Deprettere [15]は離散時変シ ステムに対して，システムマトリクスが時間的にゆっくり と変動するという仮定 (quasi-stationarity assumption) のもとで, 古い入出力デー夕に忘却係数をかけることで 逐次アルゴリズムを提案している。また， Okuは彼の学 位論文 [9]の一つの章で時変（離散時間）システムに対 する逐次 4SID 法を提案している。 そこでは，文献 [15] と同じく古い入出力データに忘却係数をかけることを提 案しているが，シミュレーションによるアルゴリズムの 有効性の検証は行われていない. しかし，システムの突 発変動の検出にそのアルゴリズムを適用して検証を行っ ている $[12]$.

本論文の 3. で導出したように同定に使用する入出力 データのサイズ $N$ を固定するのではなく, 古い入出力 データに重みをかけて現時刻での同定值へその影響を低 減しようという考えに基づいている，その考え方は，

$$
\begin{gathered}
U_{i}\left(k+1 \mid k_{0}\right)=\left[\sqrt{\lambda} U_{i}\left(k \mid k_{0}\right) \vdots u_{i}(k+1)\right] \\
Y_{i}\left(k+1 \mid k_{0}\right)=\left[\sqrt{\lambda} Y_{i}\left(k \mid k_{0}\right) \vdots y_{i}(k+1)\right]
\end{gathered}
$$

のように記述される. $\lambda(0<\lambda<1)$ が忘却係数である. この考え方に従って導かれるアルゴリズムでは, 古い デー夕を忘却係数の重みにより漸次消滅させ，最新デー 夕に重きをおいて，時変システムの同定に対処しょう としている。 この忘却係数を用いるアルゴリズムでは, データマトリクスのブロック行数の約 2 倍程度の入出力 データを保持するだけでよい.

逐次アルゴリズムは，新しいデー夕が取得されるたび に最新の同定值を生成するのが使命であるから，それ は基本的に時変システムに対処できるはずである。実 際，3. で導出したアルゴリズムはそのまま時変システ ム $\Sigma_{D}$ に対して適用できる. 著者の一人は, システム のふるまいが局所的に定常であるとみなせるという仮定 のもとで，時変システム $\Sigma_{C}$ に対する部分空間同定法を 確立しているので [7]，この“局所定常性” の仮定 (local stationarity assumption) を導入することによって，逐 次同定アルゴリズムの導出が行える。この仮定は，時変 システムのシステムマトリクス $(A(t), B(t), C(t), D(t))$ あるいは $(A(k), B(k), C(k), D(k))$ が時間的にゆっくり と変化するということを意味し, 定性的にいえば, 各マ トリクスが時間連続的かつ滑らかに变化し, 突発的変 化はしないということである。 $I_{k}$ を時刻 $t=t_{k}$ 近傍の 時間区間とし，そこではシステムマトリクス，たとえ 
ば $A(t)$ は一定，すなわち， $A(t)=A\left(t_{k}\right)=A_{k}$ ，あるい は $A(k)=A_{k}$ とみなす.このような仮定のもとで, 入出 力方程式 (4) を得ることができる.このとき，(4) 式の $\Gamma_{i}(k), H_{i}(k)$ および $\Sigma_{i}(k)$ は $A_{k}, B_{k}, C_{k}$ および $D_{k}$ に より構成されるマトリクスとなる.

\section{5. シミュレーション例}

本章では，時変システムを対象としたシミュレーショ ンを行い，提案アルゴリズムの有効性について確認す る. 連続時間システム $\Sigma_{C}$ と離散時間システム $\Sigma_{D}$ では, 入出力代数方程式を作った後の逐次アルゴリズムは同じ であるが，それまでの過程が多少異なる。連続時間シス テムに対する入出力代数方程式を作る方法は著者らの論 文 [6]を，また離散時間システムについてはVerhaegen ら [16]など多くの論文が発表されているのでそれらを参 照されたい.

\section{1 連続時間時変システム}

システムマトリクスが次のように与えられる 2 次元シ ステム $\Sigma_{C}$ を考える.

$$
\begin{aligned}
& A(t)=\left[\begin{array}{cc}
a_{11}(t) & 1 \\
-0.4 & -1
\end{array}\right], B=\left[\begin{array}{rr}
2 & 1.5 \\
-1 & 2
\end{array}\right] \\
& C=\left[\begin{array}{rr}
1 & 2 \\
-1 & 2
\end{array}\right], D=\left[\begin{array}{cc}
1.5 & 3 \\
2 & 1
\end{array}\right]
\end{aligned}
$$

ただし， $a_{11}(t)=0.1-0.3 \exp \{t / 1500\}$ である。杂隹音 $w(t), v(t)$ はそれぞれ平均值零で互いに独立, さら に共分散マトリクス $\mathcal{E}\left\{w(t) w^{\mathrm{T}}(s)\right\}=\mathcal{E}\left\{v(t) v^{\mathrm{T}}(s)\right\}=$ $0.1^{2} I_{2 \times 2} \delta(t-s)\left(I_{2 \times 2}: 2 \times 2\right.$ 次元単位マトリクス, $\delta(\cdot)$ : ディラックの $\delta$ 関数) を持つ正規性白色雑音とした. 入力 $u(t)$ は平均值零で共分散マトリクス $Q_{u}=I_{2 \times 2} \delta(t-s)$ の正規性白色雑音とした。また，同定に必要なパラメー 夕はそれぞれ $i=6, h=10, N=500$, サンプリング 間隔は $\delta t=0.01$ とした。 また，テスト関数は $\varphi\left(t ; t_{j}\right)=$ $\exp \left\{-\left(t-t_{j}\right)^{2} / 2 \sigma_{0}\right\}\left(U_{i}, Y_{i}\right.$ に対しては $\sigma_{0}=0.8, U_{h}$ に対しては $\left.\sigma_{0}=5.0\right)$ とし, 離散化パラメータ（各 $t_{j}$ 間 の間隔) は $\Delta t=0.5$ とした.

Fig.1 と Fig.2 にはそれぞれシステム極の同定值の 実部と虚部を, Fig.3には伝達零点の実部を示してお り(零点の虚部は零である), また Fig.4には (30) 式の システムの次元を判別するための固有值をそれぞれ示 した。シミュレーションでは, 定常とみなす区間 $I_{k}$ を $I_{k}=[k-N+1, k]=N \Delta t$ とし, 各図の同定值はその中 央時刻での值をプロットしている.

Figs.1-3より，同定值がシステムの真值の変化をよく 追随している様子がわかる.また, Fig.4よりシステム の次元が 2 次元であることが判断できる.

時変システムの同定に対して著者の一人が提案してい るバッチ処理方式のアルゴリズム [7]では, 計算時間が

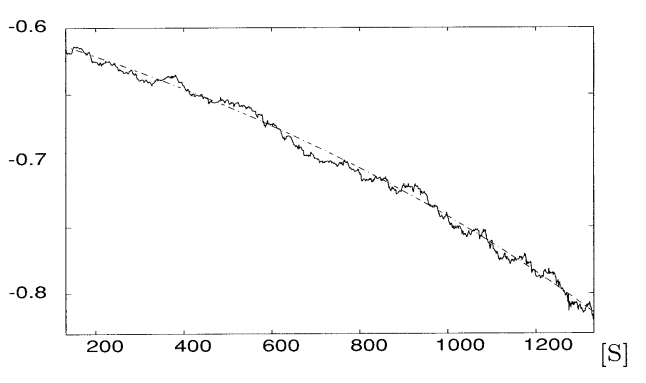

Fig. 1 Estimated real part of the pole

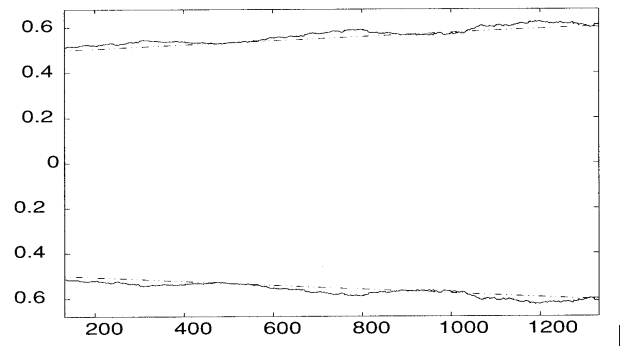

$[\mathrm{S}]$

Fig. 2 Estimated imaginary part of the pole

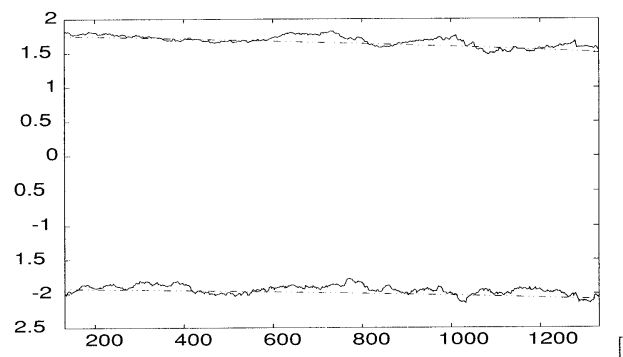

[S]

Fig. 3 Estimated real part of the transmission zero

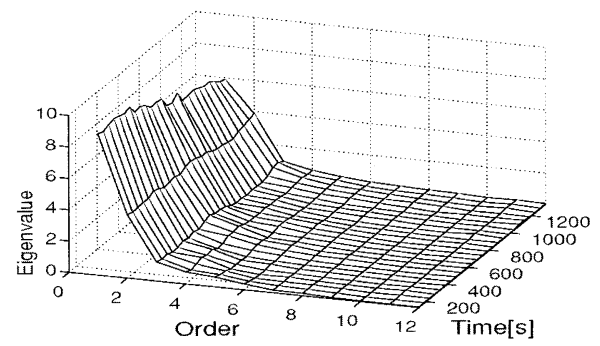

Fig. 4 Estimated eigenvalues $(N=500)$

$184.295[\mathrm{~s}]$ であるのに対し, 提案した逐次アルゴリズム では, $23.563[\mathrm{~s}]$ であり, 約 $1 / 8$ 弱の時間短縮が見られ た $[8]$.

\section{2 突発的に変化するシステムの同定}

5.1 節で考察したのと同じ連続時間システムを考える. ただし，システムマトリクス $A$ の要素 $a_{11}(t)$ が

$$
a_{11}(t)=\left\{\begin{array}{c}
-0.2(0<t \leq 700) \\
0.2(t>700)
\end{array}\right.
$$

のように $t=700$ で突発的に変化するものとする. 本論 文で導出した逐次アルゴリズムでは, 理論的には時変シ ステムに対してはシステムマトリクスは時間的にゆっく りと変化するとの仮定のもとでのみ適用可能であるが, 

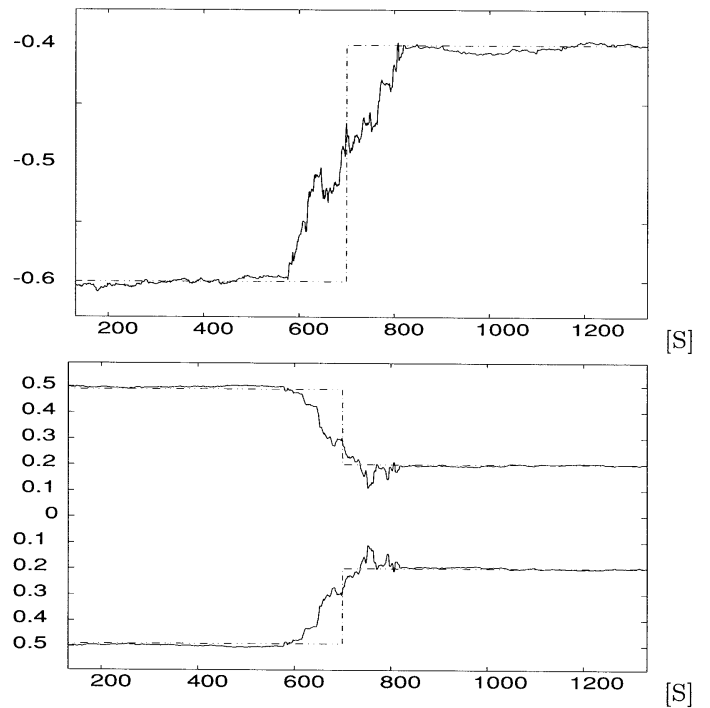

$[\mathrm{S}]$

Fig. 5 Real part (top) and imaginary part (bottom) of the estimated pole $(N=500)$

このような突発的変化にも対応できることをシミュレー ションによって示す.

Fig. 5 が， $N=500$ に対する結果である. $a_{11}(t)$ が急 激に変化する前後でゆるやかに追随している。午の追随 の速さは，データ幅 $N$ を変えることによって変わること は容易にわかるであろう。

\section{3 離散時間時変システム}

同定対象は

$$
\begin{aligned}
& A=\left[\begin{array}{cr}
a_{11}(k) & 0.4 \\
-0.4 & a_{22}(k)
\end{array}\right], B=\left[\begin{array}{rr}
2 & 1 \\
-1 & 2
\end{array}\right] \\
& C=\left[\begin{array}{rr}
1 & 2 \\
-1 & 2
\end{array}\right], D=\left[\begin{array}{cc}
1.5 & 3 \\
2 & 1
\end{array}\right]
\end{aligned}
$$

のシステムマトリクスで与えられる 2 次元システム $\Sigma_{D}$ とする．ただし， $A$ の時変要素は， $a_{11}(k)=0.1+$ $0.5 \exp \{-0.5 k / 500\}, a_{22}(k)=0.5+0.6 \exp \{-0.5 k / 500\}$ である. $w_{k}, v_{k}$ は互いに独立な雑音系列（平均值零，共 分散マトリクスはともに $\left.0.1^{2} I_{2 \times 2} \delta_{k j}\right)$, ブロックマト リクスのサイズは $i=h=10$ と設定した。 上述の設定の もとで $N=500$ (Case 1) と $N=250$ (Case 2)の二つの 場合について，それぞれ 100 回のモンテカルロ・シミュ レーションを行った。

Figs. 6，7 に Case 1 に対する同定したシステム極の 実部のサンプル平均值とそのサンプル分散值の時間的挙 動を実線で示し (破線は真值)，Fig.8 には固有値を示し た。これらの図より，同定の初期においては分散は大き いものの平均值は真值によく一致していることと，時間 が経つにつれて同定精度が良くなって行く様子がわかり， Fig. 8 に示した固有值からも, システムの次元は 2 次元 であることが判断できる。これより, 本論文の提案アル ゴリズムが有効であることが理解できる. Case 2 につい
てはFigs.9-11に示した。この場合も良好な推定結果が 得られていることから，提案アルゴリズムがデータサイ ズ $N$ に対して過敏に反応せず，安定した同定值を得るこ とができるといえる。

本論文で提案したアルゴリズムを $\mathrm{Oku}[9]$ のアルゴリ ズムによるシミュレーション結果と比較してみる。前 述したように, Oku のアルゴリズムでは忘却係数 $\lambda$ が 任意に与えるパラメータである。本シミュレーションで は， $\sqrt{\lambda}=1 \sim 0.4$ までの間の 14 種類の值を変化させた. Figs.12-16がそれらのうちの代表的な結果である。なお， Okuのアルゴリズムでは徐々にデー夕を蓄積する形と なっていることから，本提案アルゴリズムとの整合性を 保つために，デー夕幅と同じ $N=250$ ステップまでの逐 次アルゴリズムによる結果を同定の初期值として用い, それ以後の同定值をプロットしている.

Figs.12-16 より, 忘却係数を導入した $\mathrm{Oku}$ のアルゴリ ズムでは, 同定結果の平均值は $\sqrt{\lambda}$ の值を適切に選べば 本提案アルゴリズムとさほどかわりはないが，分散は忘 却係数の設定に大きく依存していることがわかる. シス テム極の虚部の同定についても同様な傾向にある．忘却 係数の役割が古いデー夕を漸次消滅させることであるこ とを想起すれば，本提案アルゴリズムに扔けるデータサ イズ $N$ がこれに相当するパラメータであるとみること ができる。このことに留意して Figs.6-11 と Figs.12-16 をみくらべると，本アルゴリズムで得られたサンプル 平均值の結果である Fig.6 あるいは Fig.9（いずれも上 図）に対応する数值結果が得られているのは Fig.15の $\sqrt{\lambda}=0.8$ の場合であるが，その場合のサンプル分散値 （Fig.15下図）は明らかに零に収束していない。計算時 間についていえば，本論文のアルゴリズムでは 1 回の試 行に要する時間は $19.9[\mathrm{~s}]$ であるのに対し，Okuのそれ は $16.2[\mathrm{~s}]$ であり, 演算速度の点からは多少優れている.

\section{6. 結 言}

本論文では，入出力データマトリクスに対する $L Q$ 分 解の $L$ 要素（の積のマトリクス）を逐次更新する逐次部 分空間同定アルゴリズムを提案した。この $L$ 要素を逐次 化することによって，入出力データサイズを固定した場 合の逐次同定アルゴリズムの導出が容易になったといえ る. 本手法は, 同定に用いる情報の量（すなわち入出力 のデータサイズ）を一定に保つことにより，時変システ ムの同定に適用可能である点が特徵となっている。また その有効性は数值例によって示された。

なお，本論文で提案した逐次アルゴリズムは一部文 献 [8]に打いて発表したものであり，その導出法と 4.1 節 で述べた他のアプローチとの比較について九州大学 和 田清教授より適切な助言を得た [18]. そのことによって 逐次同定アルゴリズムの導出がよりすっきりしたものに なったことを記し，同教授に深甚の謝意を表す。また， 査読者から適切なコメントを得, 本論文に反映させるこ 

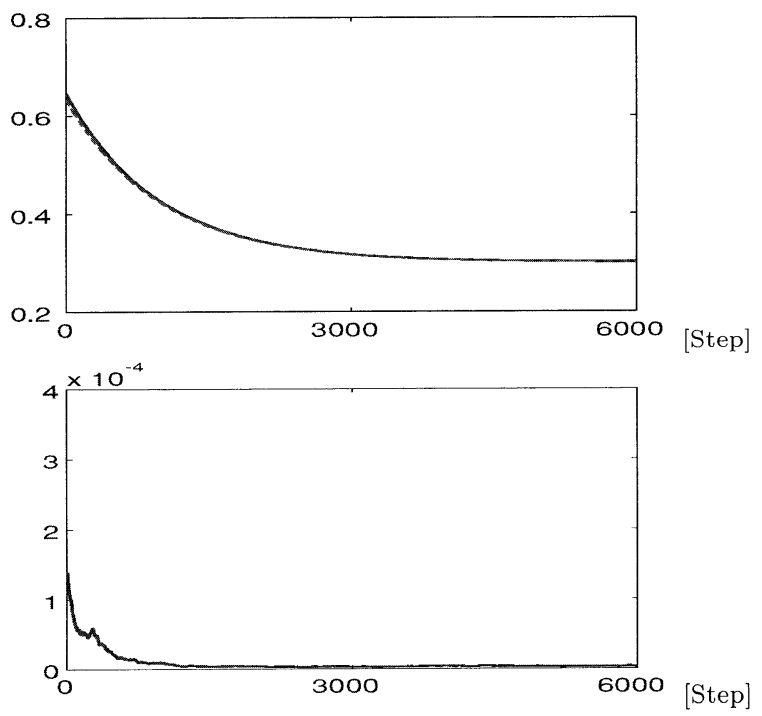

Fig. 6 Time-varying features of the sample mean (top) and variance (bottom) of the real part of estimated pole by the proposed algorithm (Case 1 . $N=500$ )
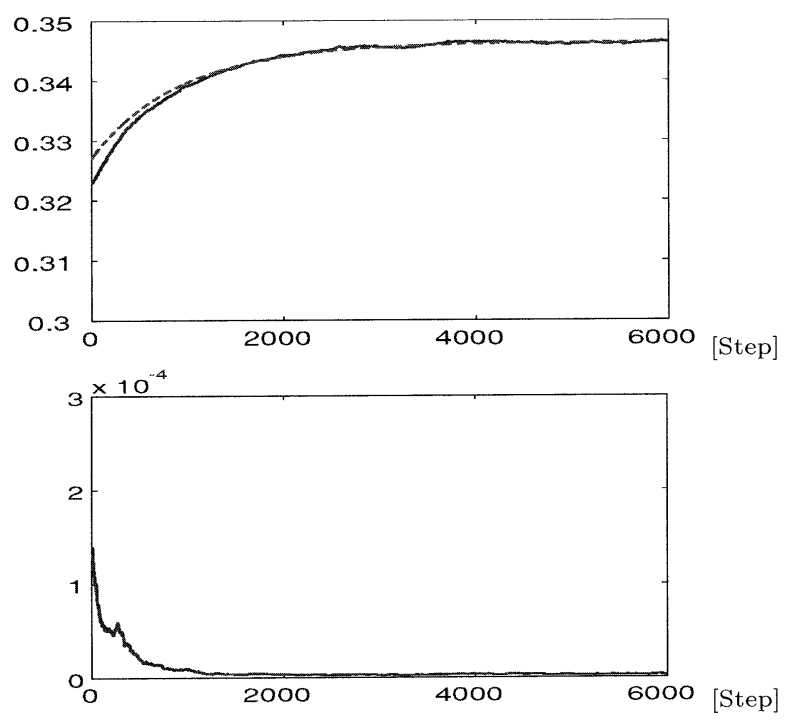

Fig. 7 Time-varying features of the sample mean (top) and variance (bottom) of the imaginary part of estimated pole by the proposed algorithm (Case 1. $N=500$ )

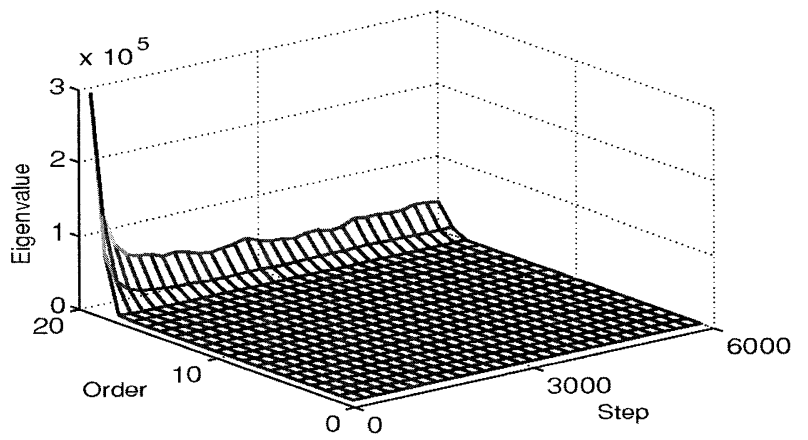

Fig. 8 Estimated eigenvalues by the proposed algorithm (Case 1. $N=500$ )
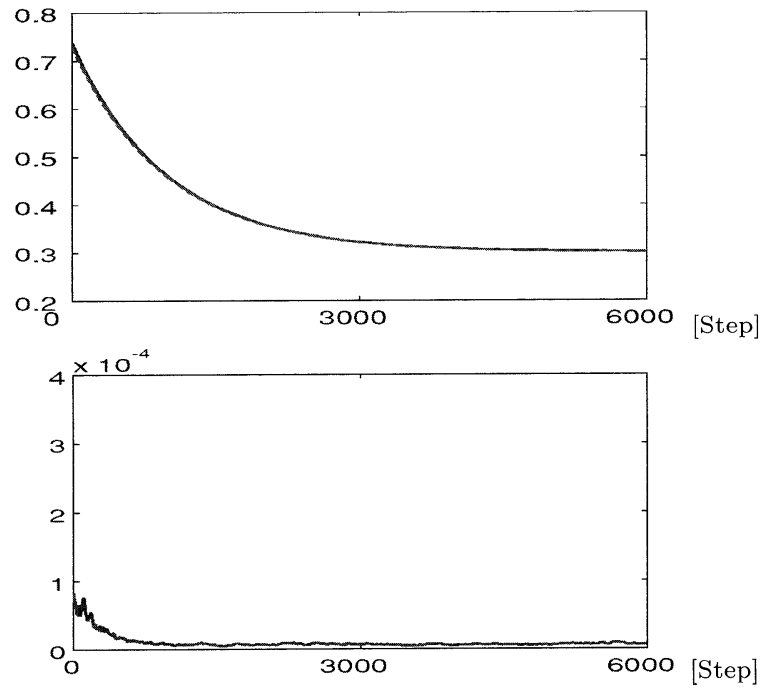

Fig. 9 Time-varying features of the sample mean (top) and variance (bottom) of the real part of estimated pole by the proposed algorithm (Case 2 . $N=250)$
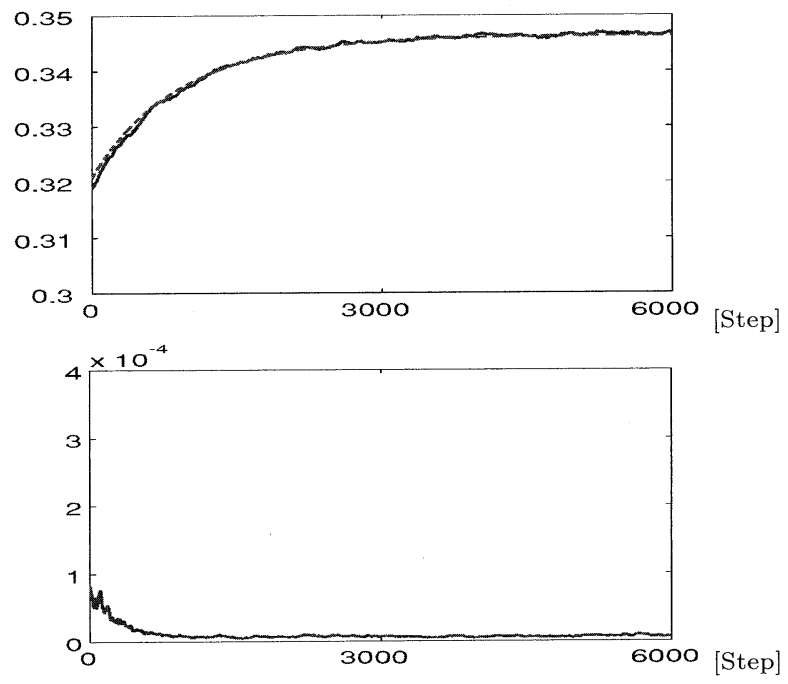

Fig. 10 Time-varying features of the sample mean (top) and variance (bottom) of the imaginary part of estimated pole by the proposed algorithm (Case 2. $N=250)$

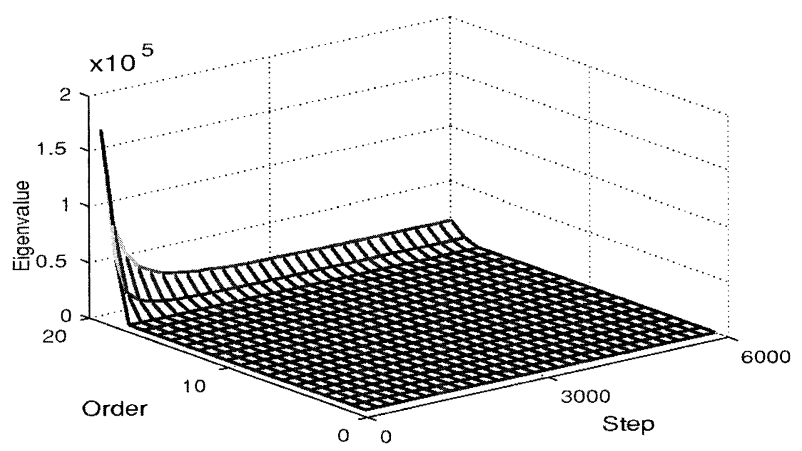

Fig. 11 Estimated eigenvalues by the proposed algorithm (Case 2. $N=250$ ) 


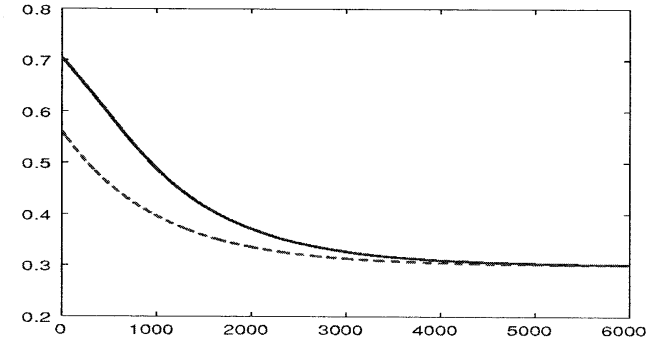

[Step]

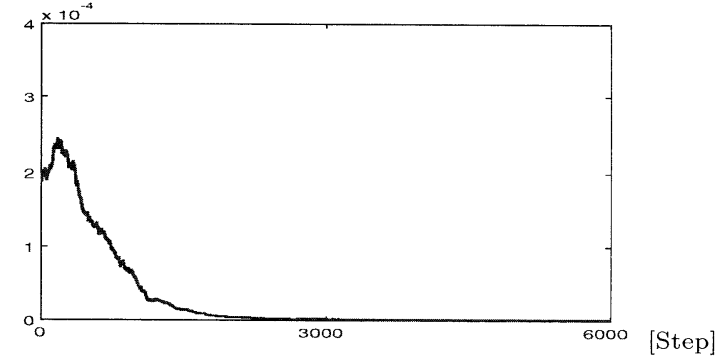

Fig. 12 Time-varying features of the sample mean (top) and variance (bottom) of the real part of estimated pole by the Oku's algorithm $(\sqrt{\lambda}=0.998)$

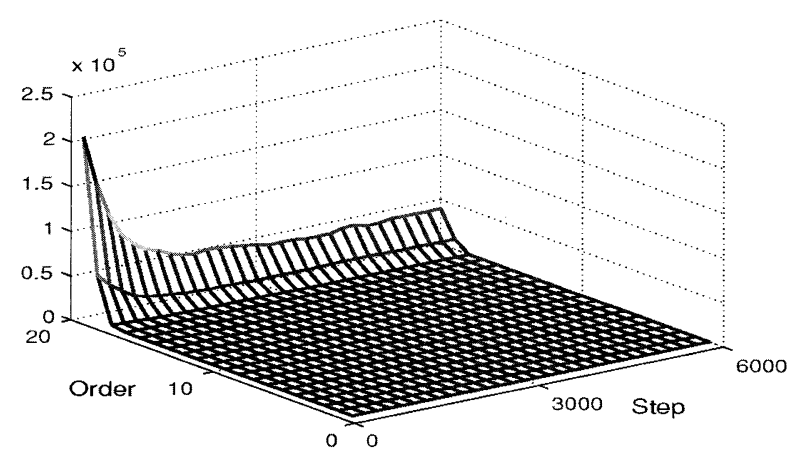

Fig. 13 Estimated eigenvalues by the Oku's algorithm $(\sqrt{\lambda}=0.998)$
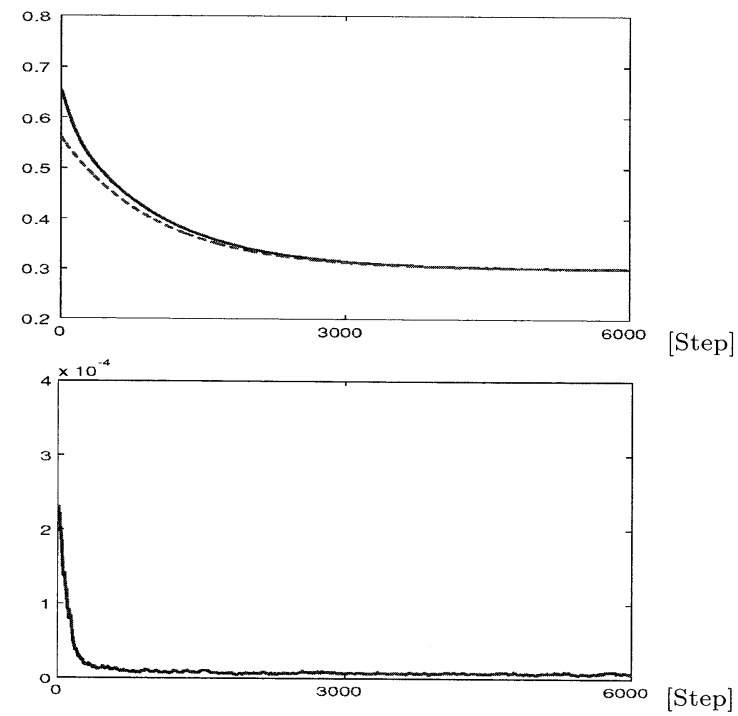

Fig. 14 Time-varying features of the sample mean (top) and variance (bottom) of the real part of estimated pole by the Oku's algorithm $(\sqrt{\lambda}=0.99)$
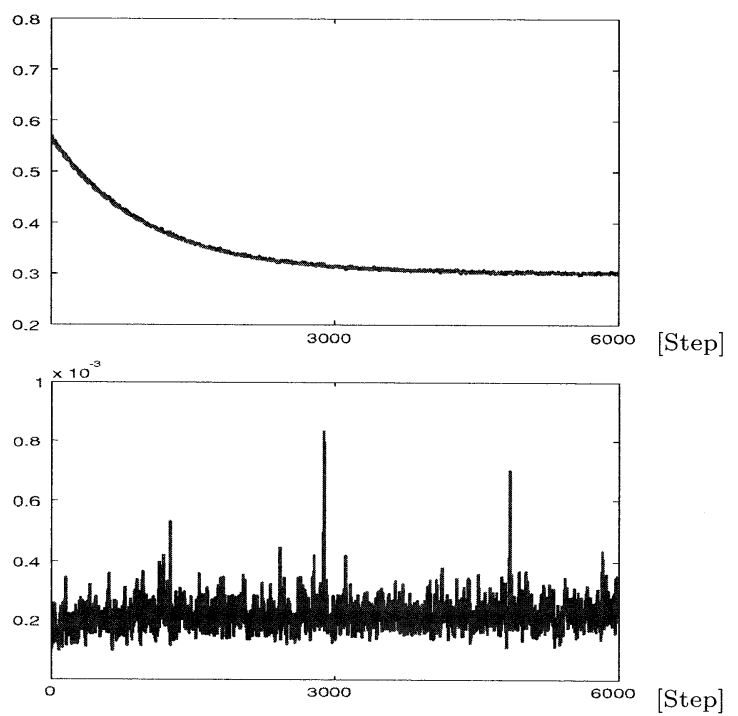

Fig. 15 Time-varying feature of the sample mean (top) and variance (bottom) of the real part of estimated pole by the Oku's algorithm $(\sqrt{\lambda}=0.8)$

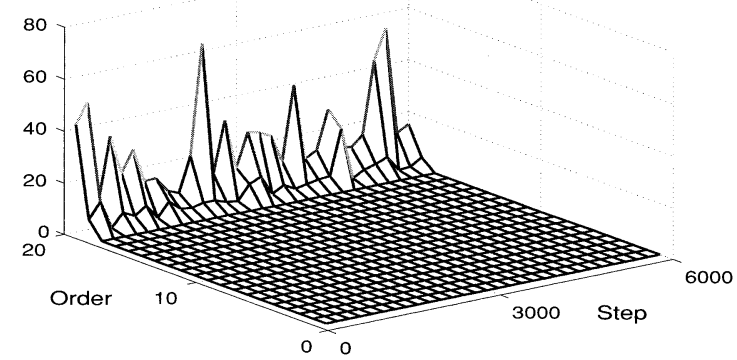

Fig. 16 Estimated eigenvalues by the Oku's algorithm $(\sqrt{\lambda}=0.8)$

とができた。併せて謝意を表す．

本研究の一部は科学研究費補助金（B）16360046に よって行われた。

\section{参 考文 献}

[1] Y. M. Cho, G. Xu and T. Kailath: Fast recursive identification of state space models via exploitation of displacement structure; Automatica, Vol. 30, pp. 4559 (1994)

[2] T. Gustafsson: Recursive system identification using instrumental variable subspace tracking; Proc. 11th IFAC Symp. System Identification (SYSID'97), pp. 1683-1688 (1997)

[3] M. Lovera: Recursive subspace identification based on projector tracking; Proc. 13th IFAC Symp. System Identification (SYSID2003), pp. 1619-1624 (2003)

[4] M. Lovera, T. Gustafsson and M. Verhaegen: Recursive subspace identification of linear and non-linear Wiener state-space models; Automatica, Vol. 36, pp. 1639-1650 (2000) 
[5] G. Mercère, S. Lecoeuche and C. Vasseur: A new recursive method for subspace identification of noisy systems: EIVPM; Proc. 13th IFAC Symp. System Identification (SYSID2003), pp. 1637-1642 (2003)

[6] A. Ohsumi, K. Kameyama and K.-I. Yamaguchi: Subspace identification for continuous-time stochastic systems via distribution-based approach; Automatica, Vol. 38, pp. 63-79 (2002)

[7] A. Ohsumi and T. Kawano: Subspace identification for a class of time-varying continuous-time stochastic systems via distribution-based approach; Proc. 15th IFAC World Congress, Vol. F, pp. 241-246 (2002)

[8] A. Ohsumi, Y. Matsuüra and K. Kameyama: Recursive subspace identification for continuous-/discretetime stochastic systems; Proc. 13th IFAC Symp. System Identification (SYSID2003), pp. 911-916 (2003)

[9] H. Oku: Sequential subspace state-space system identification and state estimation of unknown multivariable systems; Ph.D. Dissertation, Univ. of Tokyo (2000) (E-mail: oku@elc.oit.ac.jp)

[10] H. Oku and H. Kimura: A recursive 4SID from the input-output point of view; Asian J. Control, Vol. 1, pp. 258-269 (1999)

[11] H. Oku and H. Kimura: Recursive 4SID algorithms using gradient type subspace tracking; Automatica, Vol. 38, pp. 1035-1043 (2002)

[12] H. Oku, G. Nijisse, M. Verhaegen and V. Verdult: Change detection in the dynamics with recursive subspace identification; Proc. 40th IEEE Conf. on Decision and Control, pp. 2297-2302 (2001)

[13] Y. Takei, J. Imai and K. Wada: Recursive subspace identification based on subspace extraction via Schur complement; Proc. 32nd ISCIE Int. Symp. Stochastic System Theory and Its Applications, pp. 27-32 (2000)

[14] P. Van Overschee and B. De Moor: Subspace System Identification for Linear Systems; Kluwer Academic Pub (1996)

[15] M. Verhaegen and E. Deprettere: A fast recursive MIMO state space model identification algorithm; Proc. 30th IEEE Conf. on Decision and Control, pp. 1349-1354 (1991)

[16] M. Verhaegen and P. Dewilde: Subspace model identification, Part 1: The output-error state-space model identification class of algorithms; Int. J. Control, Vol. 56, No. 5, pp. 1187-1210 (1992)

[17] M. Viberg: Subspace-based methods for the identification of linear time-invariant systems; Automatica, Vol. 31, No. 12, pp. 1835-1851 (1995)

[18] K. Wada: Private communication (2003) 